\title{
Analysis Supply Chain Tangerine Orange In The District of South Central Timor
}

\section{${ }^{1}$ M. Marsela Banafanu, ${ }^{2}$ Ahmad Ramadhan Siregar, ${ }^{3} J u s n i, ~{ }^{4}$ Sitti Nurani Sirajuddin}

1AgribusinessStudy Program, Graduate School, Hasanuddin University, Makassar, 90245, Indonesia

2 Agribusiness Study Program, Graduate School, Hasanuddin University, Makassar, 90245, Indonesia

3AgribusinessStudy Program, Graduate School, Hasanuddin University, Makassar, 90245, Indonesia

4AgribusinessStudy Program, Graduate School, Hasanuddin University, Makassar, 90245, Indonesia

Correspondence Author: M. Marsela Banafanu, Agribusiness Study Program, Graduate School, Hasanuddin University, Makassar, 90245, Indonesia E-mail: mariamarsellabana@pasca.unhas.ac.id

Received date: 15 April 2019, Accepted date: 25 June 2019, Online date: 29 June 2019

Copyright: (c) 2019 M. Marsela Banafanu et al., This is an open-access article distributed under the terms of the Creative Commons Attribution License, which permits unrestricted use, distribution, and reproduction in any medium, provided the original author and source are cre dited.

\begin{abstract}
This study aimed to analyze the commodity supply chain tangerines in South Central Timor. The research was conducted in March to April 2019. From the research that there are four patterns of supply chain channel is a pattern I (farmers, traders Kupang City Kupang city Retailers -Pedagang -konsumen) pattern II (farmers, traders Kupangconsumer) pattern III (farmers - Wholesalers Retailers city Soe- consumers) pattern IV (farmers -pedagang Soe- city collector retailer-consumer Soe city) pattern V (farmers - traders Soe city - consumers). Yangdilakukan activities include exchange activity, physical and activity facilities. There are three streams that occur are the flow of goods, information flow and financial flows (financial). The main actors involved in the supply chain tangerines namely farmers, collectors Kupang, Kupang city retailers, traders town Soe city retailers.
\end{abstract}

Keywords: Supply chain, Oranges Tangerines

\section{INTRODUCTION}

In this globalization era, many challenges facing the horticultural businesses in Indonesia and East Nusa Tenggara in particular. This challenge increasingly demanded changes in accordance with the needs of a dynamic market. Currently, the horticultural farm in East Nusa Tenggara yet competitive agribusiness system and have not been able to respond to the active global marketplace. Some obstacles need to be overcome in order to develop fruits in East Nusa Tenggara were (1) Low fruit consistency of quality assurance, (2) Some types of fruits are seasonal so do not be available throughout the year, (3) Very varied varieties of fruit crops cultivated so that the production and availability for each variety of fruit is not enough because the market demand, in general, has a tendency preference to certain varieties only, (4) Crop productivity is still relatively low due to the handling of cultivation are not appropriate, (5) the area of fruit plantations are not quite vast and scattered (not compact) because pengusahaannya by traditional farmers, and (6) Support infrastructure in some areas are inadequate, making it difficult for marketing fruits. This condition needs a lot of improvement to do in Nusa Tenggara Timur associated with the strengthening of supply chain systems fruit fruits agribusiness [1].

In the agribusiness system, there is a subsystem called the supply chain system. Supply chain management system is an approach that is applied to integrate suppliers, retailers, warehouses and other storage areas efficiently so that the resulting product can be distributed to the quantity, place and the right time [2]. The framework of supply chain indicates the behaviour and interaction of complex companies. Hence, the supply chain should be designed in a way that chain network characteristics and interactions are taken into account [3]. The method of contract farming will give positive results if they are only a few players in the supply chain [4] by paying attention to three kinds of streams that must be managed in the supply chain. First, the flow of goods flowing from upstream (upstream) to downstream (downstream). Both the current of money (financial) flowing from downstream to upstream. The third is the flow of information that can occur from upstream to downstream or vice versa [5]. By maintaining the product remains fresh until up to the consumer. Distance becomes one of determining the quality of fresh produce. Therefore, the supply 
chain is not only delivered the goods to reach the consumers, but the product still has value by consumer demand. In presenting added benefit, he must emphasize the principle of efficiency to achieve the supply chain targets [6].

Tangerines (Citrus reticulata) is one of the leading commodity South Central Timor regency which has been developed by the farming community and the support from the government in the form of seeds, pesticides, and fertilizers subsidized through farmer groups. However, the facts show that the system of agribusiness tangerines currently not give prosperity to the small-scale farmers and yet provide a reasonable benefit to businesses invaluable coordination between companies, referring to the supply chain tangerines victimized in orange deliver to the end customer is a farmer. Weak bargaining position of farmers who have difficulty in marketing with because poor road infrastructures, so farmers do not want to take the risk in the marketing of tangerines that depend on middlemen. In order tangerine supply chain performance can be improved, it must take into consideration the general conditions of the supply chain and consider the key performance indicators in the supply chain. Thus, the need to do research related to supply chain analysis tangerines.

\section{MATERIAL AND METHODS}

This research was conducted in the District of North Mollo and District Fatumnasi, Kabupten South Central Timor, East Nusa Tenggara Indonesia. I am using primary and secondary data in the collection. Primary data obtained from respondents with direct interviews and a questionnaire which consisted of the characteristics of farming tangerines and distribution tangerines into the hands of consumers, secondary data obtained from research institutions involved, the Provincial Agriculture Office Nusa Tenggar East, Department of Agriculture and Plantation Kabupaaten South Central Timor, The sample in this study used a non-probability sampling as sampling technique was purposive sampling method in South Central Timor as a producer of tangerines highest in East Nusa Tenggar. While the selection of farmers using a random sampling of respondents consisted of 96 farmers and traders using snowball sampling respondents consisted of over 24 merchants. Analysis of the data used in describing the approach kuatatif Describing the flow of supply chain tangerines any activities performed by the actors who play a role in the supply chain flow tangerines in the middle East District South.

\section{RESULTS AND DISCUSSION}

\section{Overview of Supply Chain Orange Tangerines}

Picture tangerine supply chain in South Central Timor regency consists of some supply chain actors. As for the actors involved in the supply chain are the main actors and supporting actors. Each supply chain actors perform activities in accordance with their respective roles. In accordance with the opinion of In presenting added value, he must emphasize the principle of efficiency to achieve the supply chain targets [7] the supply chain has a dynamic nature but involving three constant flow, the flow of products or goods, the flow of information and the flow of money. The picture of the supply chain flow tangerines in South Central Timor can be seen in Figure1. 


Production facilites $>$ Maintenance
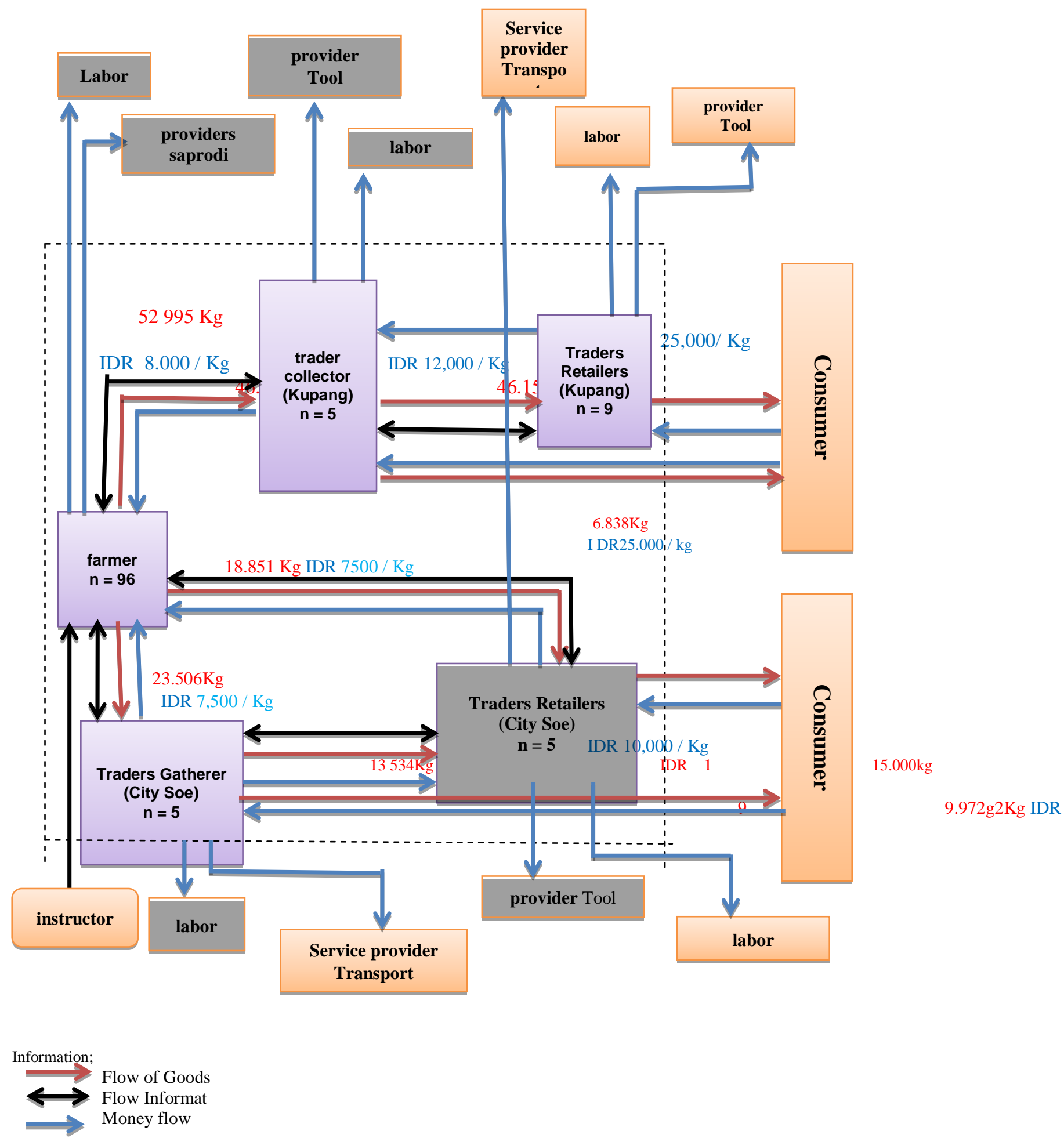

Figure 1 shows that there are five main actors in the supply chain tangerines in this research area by analyzing the three streams, namely:

\section{a. flow of Goods}

Tangerines flow starting from the farmers as producers as well as the first major actors in the supply chain tangerines in South Central Timor. Tangerines supplied by the main actors, namely the supply chain more as traders Kupang $52995 \mathrm{~kg}(55.6 \%)$, Traders in the town of Soe as many as $23506 \mathrm{~kg}(24.7 \%)$ and retailers in the town of Soe as many as $18851 \mathrm{~kg}(19.8 \%)$. So the farmer's total production of tangerines as many as $95352 \mathrm{~kg}$ in April, May, June, July through August is the harvest season. 
Tangerines in addition marketed in the town of Soe but citrus fruits are also marketed outside the territory of South-Central Timor That Kota Kupang and Atambua Kefa City. In this study, the authors only examined tangerines from South Central Timor regency is marketed in Soe city and Kupang for the supply of the best tangerines from City Kefa and Atambua. Kupang city traders who supply oranges to retailers Eosao market, Oeba in city and also directly sells citrus traders to consumers in the city of Kupang. From production received from farmers, collectors Kupang tangerines supplying to retailers Kupang as many as 46.

Although the total production of tangerines supplied to traders outside the area (Kupang) bigger, judging from the demand tangerines from Kupang City traders to farmers can be seen in (Appendix 20). Demand tangerines traders Kupang city of 77513 kilograms of citrus fruit are met while supplies only 52.995 kilos of fruit (68.4\%). Total tangerines unfulfilled supply averaged as much as 24518 kilograms of fruit (31.6\%). Based on interviews merchants Kupang that, the demand for tangerines high for sales in the capital of East Nusa Tenggara, so the demand for tangerines in large quantities to meet the consumption society in Kota Kupang but the number of production tangerine farmers are not able to meet the demand of tangerines from collectors City Kupang. Based on interviews tangerine farmers that production continued to decline last few years. This is because of citrus pests and diseases such as; diplodia, fleas (Diaphonia Citri).

\section{b. Information flow}

Supply chain management as a powerful tool in any company should be accurately examined for identifying its problem for that managers can make a correct decision [7]. The information flow is happening in the supply chain tangerines contained on the location of the research shows that the flow of information is already well integrated. Communication activities conducted by telephone and at the time the two sides meet each other directly. Information farmers to traders outside the territory of SouthCentral Timor (Kupang) and retailers in the city of Kupang that tangerines are ready to be harvested and marketed to consumers. Similarly, what happens to traders in the district of South-Central Timor obtain information via cell phones from farmers about ready for harvesting tangerines was forwarded to the retailers in the urban area town Soe that tangerines are ready to be harvested and marketed to consumers.

But before going on communication between farmers and traders for traders and retailers have done the entire stock system so that farmers simply convey information oranges ready for harvest. Based on interviews with farmers in the location study that farmers tangerines in the study site does not sell directly to consumers by selling his oranges to the trader with the entire stock because it is more efficient system is not draining, the money and the time to sell yourself. And another reason Soe road access to the city due to a lot of asphalt that has been perforated so that the farmers are afraid of citrus fruits to be damaged so do not want to burden the marketing risk.

\section{c. Money flow}

In this study, the flow of money stems from farmers to buy inputs such as fertilizer, pesticides to support the process plant maintenance tangerines with a cost of IDR 398228 per hectare crop of tangerines or IDR 33,185 per crop tree tangerines with total expenses of production facilities of the IDR 25.614 million. Farmers incur the cost of agricultural labor is IDR 20,000 per person-days with a total agricultural labor pengeluarkan IDR 17.4696 million. The selling price of tangerine growers to traders mussel town of IDR 8,000 per kilogram of fruit with a total production of 52995 kilogram supplied fruit so that the acceptance of IDR 423.956 million (57.2\%), tangerine farmer selling price to farmers Soe city traders of IDR 7,500 per kilogram with a total production of 23506 kilogram supplied fruit to gain acceptance of IDR 176.295 million (23.8\%), tangerine farmer selling prices to retailers Soe town of IDR 7,500 per kilometer pieces with a total production of 18851 kilograms total supply of fruit so that the acceptance of IDR 141382500 (19.1\%). So, the total admission citrus farmers in the research area are IDR741.633.000.

Kupang city traders as the purchase cost of tangerines from farmers at IDR 8,000 per kilogram of fruit so that the total expenditure for the purchase of tangerines as much as 52995 kilograms of IDR 423.96 million, for the purchase of equipment in support to post-harvest activities such as marketing tangerines; used sacks, tarpaulins, large buckets, plastic bags fixtures harvest, post-harvest and marketing of IDR 5.762 million. Meanwhile, wages for farm laborers harvesting, transporting, cleaning up marketing tangerines IDR 20,000 per person-days with total wages paid amounting to IDR2.634 million sale price collectors to retailers Kupang city in the range of IDR 12,000 per kilogram of fruit with so as to obtain acceptance of IDR 553884.

Retailers Kupang making purchases from trader's orange Kupang city by spending tangerines purchase of IDR 12,000 per kilogram of fruit with a total purchase of IDR553.884 million. For the purchase of equipment in support to post-harvest activities such as marketing tangerines; used sacks, tarpaulins, large buckets, plastic bags IDR 4.382 million. traders immediately ushered into the fruit tangerine orange sales are oeba market and markets in the city of Kupang Oesao so there is no flow of money that goes through the provider of public transport conveyances. Wages are used only for cleansing of citrus fruits and the marketing of IDR 20,000 per person-days with total wages paid amounting to IDR 7,951.

Soe City traders to pay in the form of purchases of tangerines in farmers amounting to IDR 7,500 per kilogram of fruit so that the total expenditure for the purchase of tangerines as much as 23506 kilograms of IDR 176.295 million. , For the purchase of equipment in support to post-harvest activities such as marketing tangerines; used sacks, tarpaulins, large buckets, plastic bags IDR 4.418 million. Meanwhile, wages for farm laborers harvesting, transporting, cleaning fruit tangerine tangerines up marketing of IDR 20,000 per person-days with total wages paid amounting to IDR 3,700,000. There is a cash flow that occurs between collectors in the Middle East region South provider of public transport conveyances containing tangerines of tangerines growers, retailers cost IDR 7.005 million,

Retailers in the city of oranges Soe make purchases from farmers and traders, with pay buying tangerines IDR 7,500 per kilogram of fruit from citrus growers with a total purchase price of IDR 141382 500. 10,000 per kilo, while the fruits are buying tangerines out of Soe City traders with total purchase tangerines IDR 135.34 million, bringing the total expenditure retailers in the purchase 
of oranges, is IDR 276722 500. To purchase the harvest and post-harvest equipment that supports the marketing of tangerines like; gala, used sacks, rope, tarpaulins, large buckets, plastic bags IDR 4.989 million, There is a cash flow that occurs between collectors in the Middle East region South provider of public transport conveyances containing tangerines of tangerines farmers to the point of sale merchant in the city of Soe, the costs incurred by IDR 7.460.000 retailers. Wages for harvesting, transporting, cleaning and marketing of citrus fruits amounted to IDR 20,000 per person-days with total wages paid amounting to IDR 10.757 million. Receipts obtained from the sale of tangerines to consumers amounting to IDR 15,000 per kilogram of fruit to get the total revenue of IDR 485.775 million. 20.000 per HOK, with total wages paid amounting to IDR 10.757 million. Receipts obtained from the sale of tangerines to consumers amounting to IDR 15,000 per kilogram of fruit to get the total revenue of IDR 485.775 million. 000 per HOK with total wages paid amounting to IDR 10.757 million. Receipts obtained from the sale of tangerines to consumers amounting to IDR 15,000 per kilogram of fruit to get the total revenue of IDR 485.775 million.

\section{Activities Supply Chain Actors}

The logistics and supply chain management are no doubt one of the critical success, should the country and its economy be competitive and survive [9]. Activities in the supply chain begin with the demand from consumers and end with the activity of payment by the consumer after the request is fulfilled. According to [10], the entire company or related organization is divided into two primary members and supporting members. Primary principal member or members of a supply chain is all business units that actually perform operational or managerial activities in a business process. the method of contract farming will give positive results if they are only a few players in the supply chain). Disorganized condition of selection as well organizing of human capital in-country and necessity of paying attention to the issue in better managing the supply chain in business and the significant importance of the matter in achieving competitive advantages [11].

While supporting member or supporting members in the supply chain are companies that provide starting materials, science, utilities, or other assets that are important but not directly participate in activities that generate or change an input to output for consumers In the supply chain tangerines South Central Timor there are two types of actors, namely the main actors and supporting actors. As for the activities of the main actors in the supply chain tangerines in Table 1.

Table 1 Activities Principal Supply Chain Orange Tangerines in South Central Timor in 2018.

\begin{tabular}{|c|c|c|}
\hline No. & $\begin{array}{l}\text { Main actors } \\
\text { Supply chain }\end{array}$ & Activity \\
\hline 1. & Farmer & $\begin{array}{ll}\checkmark & \text { Purchase of production facilities for the plant maintenance } \\
\text { tangerines } \\
\checkmark & \text { Perform maintenance on the plant tangerine } \\
\checkmark & \text { Harvesting }\end{array}$ \\
\hline 2. & $\begin{array}{l}\text { traders Gatherer } \\
\text { Kota Kupang }\end{array}$ & $\begin{array}{ll}\checkmark & \text { Sorting } \\
\checkmark & \text { Collecting and buying tangerines farmers } \\
\checkmark & \text { Packing } \\
\checkmark & \text { Pegangkutan harvest } \\
\checkmark & \text { Tangerines kepedagang retailers sell Kupang and Consumers }\end{array}$ \\
\hline 3. & $\begin{array}{l}\text { traders Pengecerl } \\
\text { Kota Kupang }\end{array}$ & $\begin{array}{ll}\checkmark & \text { Buy oranges from traders Kupang } \\
\checkmark & \text { Cleaning oranges from dirt / soil } \\
\checkmark & \text { Sell to the consumer }\end{array}$ \\
\hline 4. & $\begin{array}{l}\text { traders Pemgumpul } \\
\text { Kota Soe }\end{array}$ & $\begin{array}{ll}\checkmark & \text { Sorting } \\
\checkmark & \text { Collecting and buying tangerines farmers } \\
\checkmark & \text { Packing } \\
\checkmark & \text { Transporting crops } \\
\checkmark & \text { Sell tangerines kepedagang Soe City retailers and consumers }\end{array}$ \\
\hline 5. & $\begin{array}{l}\text { Wholesalers Retailers Soe } \\
\text { City }\end{array}$ & $\begin{array}{ll}\checkmark & \text { Tangerines buy from farmers and between regions } \\
\checkmark & \text { Transportation CROPS } \\
\checkmark & \text { Sorting } \\
\checkmark & \text { Packing } \\
\checkmark & \text { Tangerines sell to consumers }\end{array}$ \\
\hline No. & $\begin{array}{ll}\text { Performers } & \text { Supply } \\
\text { Chain Support } & \end{array}$ & Activity \\
\hline 1. & Consumer & Eating tangerine \\
\hline 2. & $\begin{array}{l}\text { Wholesalers Retailers } \\
\text { Kupang }\end{array}$ & $\begin{array}{ll}\checkmark & \text { Buying tangerines out of traders Kupang } \\
\checkmark & \text { Tangerines sell to consumers }\end{array}$ \\
\hline 3. & means of Production & $\begin{array}{l}\checkmark \text { Provide inputs (fertilizers, pesticides and herbicides) needed for } \\
\text { farming tangerines }\end{array}$ \\
\hline 4. & Farm workers & $\begin{array}{l}\checkmark \text { Providing services for maintenance of farmland tangerines until } \\
\text { ready for harvest managed by farmers }\end{array}$ \\
\hline
\end{tabular}




\begin{tabular}{|l|l|rr|r|}
\hline & & $\checkmark$ & $\begin{array}{l}\text { Providing services for the harvesting activity in farmland tangerine } \\
\text { tangerines }\end{array}$ \\
\hline 5. & $\begin{array}{l}\text { Penyedai Public Transport } \\
\text { Services }\end{array}$ & $\checkmark$ & $\begin{array}{l}\text { Tangerines provide transport services from farmers farming land } \\
\text { to the place of sales traders and retailers in the town of Soe } \\
\text { processing tangerines }\end{array}$ \\
\hline 6. & Instructor & $\checkmark$ & $\begin{array}{l}\text { Technical guidance to farmers on cultivation tangerine tangerines } \\
\checkmark\end{array}$ \\
\hline
\end{tabular}

\section{CONCLUSION}

Supply chain tangerines South Central Timor regency consists of the main actors and supporting actors. The third stream in the supply chain looks good research sites, including tangerine arrival punctuality in accordance with customer demand. Tangerines flow of goods amounted to 41942 kilograms of fruit by 14067 requests fulfilled but tangerines unmet traders retailers Kupang to Kupang for five years tangerine production is decreasing and this is because citrus pests and diseases such as; diplodia, fleas (Diaphonia Citri), fruit flies (Dacus sp), CVPD, root rot, fruit fall prematurely, and stem rot, causing the smaller citrus fruits and even cause the plants to die. supply chain information flow tangerines already well integrated between supply chain actors and the flow of money in accordance with the agreement supply chain actors.

\section{REFERENCES}

[1] Herman, Lalel. 2013. Strengthening Agro-Industry In East Nusa Tenggara In The Framework Challenge Imported Fruits Handling Through Post-Panen.Undana.

[2] Marimin, Taufik D, Et al, 2013.Technique and Fuzzy Decision Analysis in Supply Chain Management. Publisher IPB Press. Bogor.

[3] Rashidi, S. F., \& Barati, R. (2014). On the comparison of supply chain with Sub-Dmus in Dea. Advances in Environmental Biology, 8(7), 2387-2390.

[4] Widyadana, G. A., Octavia, T., Palit, H. C., \& Gunawan, G. A. (2014). The Impact of Contract Farming on Banana Supply Chain Performance in East Java, Indonesia. Australian Journal of Basic and Applied Sciences, 8(14 Special), 90-95.

[5] Pujawan.2005.Supply Chain Management. Surabaya; Widya Guna.

[6] Sirajuddin, S. N., Mappangaja, A. R., Darma, R., \& Sudirman, I. (2015). Value added analysis of beef cattle supply chain actors micro-scale community farm based. American-Eurasian Journal of Sustainable Agriculture, 9(7), 7-12.

[7] Chopra, S dan Meindl, P. 2004.Supply Chain Management.New Jersey; Pearson Education.

[8] Moradi, M. R., \& Rahmani, M. (2014). Strategic management supply chain management during uncertainties. Advances in Environmental Biology, 1768-1776.

[9] Ramingwong, S., \& Sopadang, A. (2015). Simulating Benefits over Supply Chain Redesign Strategies. Journal of Applied Science Research, 7-10.

[10] Stock, James R. and Douglas M. Lambert. Logistics Management Strategy 2001. Fourth ed. Singapore: McGraw-Hill Higher Education.

[11] Dushanbe, T. (2015). Integrated human resource supply chain management: a model for organizational excellence. Advances in Environmental Biology, 9(3), 185-194. 